\title{
Yaddo: Assigned Their Room
}

Mine for a month was the bed where they slept, idled away afternoon hours, retreated to read a book or lounge about, making love.

The satin bobble-skirted lamp red as a brothel's was the same that had thrown light on their bodies, and the brass globes of the bedposts reflected

miniature me for that month instead of lovely them as they had moved about like ordinary people who just happened to be destined for adulation.

I would love to hear what they had talked about, but the room was silent as a tomb. She, Sylvia, was pregnant and still in love and awe of Ted,

and claimed she had never been happier, although the grand affliction of success was already setting in like a contagion grim as the plague. As I strolled

around the small lakes where they had once taken out the rowboat that was still there these decades later I thought of this couple who were soon off, over

the ocean, out of range of simplicity, serenity, happiness. I sat at the oak table they had shared in the bliss of mutual creation and almost, almost heard them tiptoe, but for thirty days and nights they ignored me. 